\title{
New Face of International Law From Western to Global Construct
}

\author{
Atip Latipulhayat* \\ DOI: https://doi.org/10.22304/pjih.v7n1.a3
}

Submitted: February 22, 2020 | Accepted: April 30, 2020

\begin{abstract}
The modern international law, not only imitates, but the substance is truly the European values and traditions. The European nations produce the norm of international law with a clear objective is to divide the world into "selves" (European nations) and "others" (nonEuropean nations). This is exacerbated by European colonialism and imperialism, which allow their values and traditions to become hegemonic norms that ultimately produce the paradigm of "otherness" in international law. Non-European nations are "others", which are considered only as users of the European values. The "otherness" paradigm in international law is resulted from the universal claim of the European values. It is a hegemonic technique. The paper argues that International law should move from the "otherness" to the "togetherness" paradigm. This requires a new approach in the making of international norms, from claim to consent, and now it has led to the global values approach. The paradigm of togetherness requires an inter-civilizational approach, and universality is the keyword. Universal norms should not be put on an abstract level; they need transformation into the particular idioms. Universality is not a matter of claim; it is a respect and acceptance of cultures and values of other nations. International law requires a paradigm shift, from Western to Global Construct.
\end{abstract}

Keywords: global construct, international law, western.

\section{Wajah Baru Hukum Internasional Dari Konstruksi Barat ke Konstruksi Global}

\begin{abstract}
Abstrak
Hukum internasional modern, tidak hanya meniru, tetapi substansinya sepenuhnya adalah nilai-nilai dan tradisi Eropa. Negara-negara Eropa memproduksi norma hukum internasional dengan tujuan yang jelas, yakni untuk membagi dunia menjadi "selves" (bangsa Eropa) dan "others" (bangsa non-Eropa). Hal ini diperburuk oleh kolonialisme dan imperialisme Eropa, yang memungkinkan nilai-nilai dan tradisi mereka menjadi norma-norma hegemonik yang pada akhirnya menghasilkan paradigma "otherness" (keberlainan) dalam hukum internasional. Negara-negara non-Eropa adalah "others" (liyan) yang dianggap hanya sebagai pengguna nilai-nilai Eropa. Paradigma "otherness" dalam hukum internasional lahir dari klaim universal nilai-nilai bangsa Eropa. Ini adalah teknik hegemonik. Tulisan ini berpendapat bahwa hukum internasional harus berubah dari paradigma "otherness"
\end{abstract}

PADJADJARAN Journal of Law Volume 7 Number 1 Year 2020 [ISSN 2460-1543] [e-ISSN 2442-9325]

* Professor of International Law, Faculty of Law Universitas Padjadjaran, Jalan Dipati Ukur No. 35, Ph.D, LL.M. (Monash University), S.H. (Universitas Padjadjaran), atip.latipulhayat@unpad.ac.id/ atiphayat@gmail.com. 
(keberlainan) ke "togetherness" (kebersamaan). Paradigma ini mensyaratkan pendekatan baru dalam pembuatan norma-norma internasional, dari klaim ke persetujuan (negara), dan saat ini telah mengarah pada pendekatan nilai-nilai global. Paradigma kebersamaan membutuhkan pendekatan antar-peradaban, dan universalitas adalah kata kuncinya. Norma-norma universal tidak boleh diletakkan pada level abstrak; mereka membutuhkan transformasi kedalam idiom-idiom yang lebih detail dan spesifik. Universalitas bukanlah masalah klaim; tetapi merupakan penghormatan dan penerimaan budaya dan nilai-nilai negara lain. Hukum internasional membutuhkan perubahan paradigma, dari konstruksi Barat ke konstruksi global.

Kata kunci: hukum internasional, konstruksi barat, konstruksi global.

\section{A. Introduction}

International law is norms that contain universal values, a blended of various cultures and values of the nations in the world. However, history and its reality demonstrate that international law is truly rooted in cultures and traditions of the European nations. Colonialism and imperialism have played a significant role in making European cultures and traditions become universal values and norms. The application of the European values and traditions into non-European nation legal systems is a (political) imposition rather than voluntary acceptance. One of the serious consequences of that is the hegemony norm in the sense of superiority claims of the European values and traditions over the non-European nations. Although European colonialism and imperialism are history, the norms and practices of international law have not completely freed from the domination of European nations or still reflecting the systems and practices that are Eurocentric in nature.

The paper argues that International law needs a paradigm shift, from Western to Global Construct. International law should represent a common law of mankind instead of a European national law. The main problem lies not in the international law-making process; it is about the hegemony of norms. The hegemony of the European values and norms in the creation of international law has made this law not only is Eurocentric in nature but to a certain extent has been eroding the nature as well as the international element of international law. This hegemony of norms has been a reductionist element that ultimately will erode the universality of international law.

\section{B. Eurocentrism in International Law}

The modern international law, not only imitates, but the substance is truly the European values and traditions. ${ }^{1}$ Most international jurists in the West claimed that

Martti Koskenniemi, "International Law in Europe", European Journal of International Law, Vol. 16, No.1, 2005, p. 113. 
international law, especially from the $16^{\text {th }}$ to $18^{\text {th }}$ century, was actually the European system of law. More specifically some have claimed that international law is a product of European Christian community awareness that carries universal meaning and suggested that it could reach non-Christian community. ${ }^{2}$ This selfclaimed of superiority has led the European to be a "civilized nation". The massive and expanding European colonialism in Asia and Africa, in particular, had brought about the colonized people as "non-civilized" nations.

Eurocentrism is an epistemic and not a geographic issue. ${ }^{3}$ It refers to a concept created to build a theological as well as a secular system for an entity called Europe. It is not an existing entity where Eurocentrism one day emerged; it is an invention of Eurocentrism. ${ }^{4}$ If Eurocentrism is not geographic but an epistemological issue, the crucial point is not to ask what Europe is but how such en entity came to be what it is. Thus, Eurocentrism names the locus of enunciation that invented a territory called Europe. ${ }^{5}$ Eurocentrism is not only the history, but also the reality of Europe. It is their geographical, political and conceptual centre. ${ }^{6}$ It represents the interests and values of the European people that form their civilization. The history of international law is part of the expansion of European civilization over the world. ${ }^{7}$ Grovogui argues that the interest of Europe in building its own ius publicum is at the expense of the rest of the world being expropriated and appropriated by means of international law and cartography. ${ }^{8}$ In the formation of international law, eurocentrism is a hegemonic norm to strengthen political position in their colonies.

The hegemony of European values and colonialism are the most crucial factors that made modern international law are associated with the values and traditions of the European nations. They enjoyed their superiority norms and practices that ultimately made the European were confident to declare and claim as a major or even the sole contributor to the establishment of the law of nature and law of nations (international law). ${ }^{9}$ Hersch Lauterpacht, for instance, claimed that the rights in the Universal Declaration of Human Rights were attributed to the tradition of British liberalism. Baron Descamps, Belgian international lawyer and member of the Comite des juristes that drafted the Statute of the Permanent Court of International Justice proposed "general principles of law recognized by civilized

2 See also H. Steiger, "From the International Law of Christianity to the International Law of the World Citizen: Reflections on the Formation of the Epochs of the History of International Law", Journal of the History of International Law, Vol.2, Issue 3, 2001, p. 183.

3 Aníbal Quijano, "Coloniality and Modernity/Rationality", Cultural Studies, Vol. 21, No. 2-3, 2007, pp. $168-78$.

$4 \quad$ Walter D. Minoglo, "The Making and Closing of Eurocentric International Law: The Opening of a Multipolar World Order", Comparative Studies of South Asia, Africa and the Middle East, Vol. 36, Issue 1, 2016, p. 183. Ibid., p. 184.

See also Martti Koskenniemi, "Histories of International Law", Rechtsgeschichte, Vol. 19, 2011, p. 154.

Ibid.

Minoglo, op.cit., p. 185.

Koskenniemi, International Law in Europe, op.cit., p. 114. 
nations" (emphasis added) were inserted in the list of sources of the Court was to apply. ${ }^{10}$

Hegemony is associated with predominant power or influence. It is a predominant influence, as of a state, region, or group over another or others. Hegemony is a concept of power in various forms and manifestations, which can take for instance in the form of cultural, political, or economic hegemony. This is accompanied by the element of tacit consent of the powerless to dominant power. The distinct phenomenon resulted from a hegemonic power is the creation of unequal relation and interaction between powerful and powerless nations. Modern international law is formed in the era of colonialism that put Europe as the powerful nations and the powerless nation is non-European countries. Hence, colonialism and hegemony like the two sides of the one coin. Colonialism works through three basic operations: (1) massive land appropriation, for which international law was necessary; (2) massive exploitation of labour, for which racism was necessary to justify the colonial destruction to the civilization of their colonies; and (3) the emergence of an economy that consisted in investing the surplus to increase production and, therefore, to create and expand the global market. ${ }^{11}$

\section{Colonialism and International Law}

Colonialism is part of the history and politics of the European countries. It refers to the territorial annexation and occupation of the non-European territories by the European State. ${ }^{12}$ Annexation, occupation, and non-European territories are the keywords of the colonialism, which all suggests that non-European countries are subject to domination. More specifically, colonialism needs power, domination, hegemony, and control. Thus, culture, economy, politics, and the entire complex of ideas of the colonial relation are seen in the light of power or force. ${ }^{13}$ At the practical level, colonialism goes hand in hand with imperialism, as they have the same objective, to rule and control non-European countries. The difference lies in its motivation; colonialism is politically motivated while imperialism has economic motives. Hence, imperialism refers to the spread and expansion of industrial and commercial capitalism. ${ }^{14}$ Etherington provides a broader definition of imperialism as follows: "...the search for investment opportunities and markets for surplus capital and productive capacity, despotic methods of government, empire-building,

\footnotetext{
10 Martti Koskenniemi, The Gentle Civilizer of Nations: The Rise and Fall of International Law 1870-1960, Cambridge: Cambridge University Press, 2011, p. 163.

Minoglo, op.cit. p. 183.

12 James Thuo Gathii, “Imperialism, Colonialism, and International Law”, Buffalo Law Review, Vol. 54, No. 4, 2007, p. 1014.

$13 \quad$ Ibid., p. 1016.

$14 \quad$ Ibid., p. 1014.
} 
and employing the power of the armed state to secure economic advantages in the world at large". ${ }^{15}$

The British relationship with its colonized countries in the nineteenth century provides an interesting illustration concerning the hegemony of European norms and rules. The British imperialism and colonialism applied international law and English law for the following objectives. First, to show that international legal doctrines surrounding British protectorates of the nineteenth century did not distinguish between imperialism as represented by the introduction of rules and practices of English private and business law into the colonies, on the one hand, and colonialism, particularly as exemplified by rules of acquisition of title to territory, on the other. ${ }^{16}$ Secondly, it was to show that the imposition of the colonial rule went hand in hand with the imposition of English rules of property, tort, and contract. Consequently, there was a close relationship between rules of public international law and those of English rules of property, tort, and contract in nineteenth-century protectorate jurisprudence. ${ }^{17}$ More importantly, this demonstrates that colonialism and imperialism need a legal justification and international law has to be proved a proper law - the first step in the justification of the politico-economic project of colonization. ${ }^{18}$ Antony Anghie insists that colonialism is the central element in the development of modern international law. He argues further that international law has always been animated by the civilizing mission, the project of governing and transforming non-European peoples, and that the current war on terror is an extension of this project. ${ }^{19}$

The universalization of international law is principally the political by-product of European colonialism and imperialism. ${ }^{20}$ It can be seen for instance, in the use of several terms in international law that are considered of having universal recognition, in fact, it is indeed a colonial practice as a political device to perpetuate their domination over the colonized peoples. This might be represented by investigating the origins of the three following terms; piracy, sovereignty, and discovery. Piracy in the high seas is actually the practice of what is known as civilized nations. This is created as a political term to maintain their control over the ocean for military and commercial purposes in particular. It is subsequently completed by the victory of the concept of an open sea over the close sea arguments in the battle of the books and this marked the culmination of the era of

15 Norman Etherington, Theories of Imperialism: War, Conquest and Capital, New York: Rutledge Revivals, 1984, p. 5.

Gathii, op.cit. p. 1014.

Ibid.

Prabhakar Singh, "From 'Narcissistic' Positive International Law to 'Universal' Natural International Law: The Dialectics of 'Absentee Colonialism", African Journal of International and Comparative Law, Vol. 16, No. 1, 2008, p. 57.

19 Antony Anghie, "The Evolution of International Law: Colonial and Postcolonial Realities", Third World Quarterly, Vol. 27, No. 5, 2006, pp. 739-753.

$20 \quad$ Singh, op.cit., p. 59. 
colonialism. $^{21}$ Sovereignty is a discriminatory political term. The meaning and application are different when it is applied in Europe and Asia or Africa. For European purposes, sovereignty has a limited meaning; it never extended beyond the political and geographical limits of Europe. However, in the context of Asia and Africa, sovereignty should be read as complete control of the European colonizers over colonized peoples for political and commercial purposes. ${ }^{22}$

The majority of the non-European nation was colonized under an international legal principle that is known today as the doctrine of Discovery. This doctrine is one of the important principles of international law used by Europeans to occupy the lands and seize the rights of non-European peoples. It had gained religious, racial, and ethnic justification that made European and Christian were confident to claim their superiority over other peoples and religions. As a result, it automatically conferred the Europeans the rights to acquire property rights in the native lands and gained governmental, political, and commercial rights over the indigenous inhabitants without their knowledge or consent. ${ }^{23}$ The United States Supreme Court had clearly defined the doctrine of discovery in its decision on Johnson $v$. M'Intosh (1823). The Court held that the Doctrine was an established legal principle of European and American colonial law and was also the law of the American state and federal governments. More importantly, the Court read and interpreted Discovery as the rights of the European Christian when discovered lands unknown to Europeans, they automatically obtained sovereign and property rights in the lands, even though indigenous people were already occupying and using them. This transfer of rights was accomplished without the knowledge or consent of native peoples. ${ }^{24}$

There are ten elements that form the doctrine of Discovery, which absolutely smack of European colonialism and values, and the four of them are considered controversial due to discriminatory, superiority, and racial content. First, indigenous limited sovereign and commercial rights. Indigenous peoples are deemed to have lost aspects of inherent sovereignty and rights to international trade and diplomatic relations. They are only allowed to interact with their discoverer. Second, civilization. Europeans claim that civilization and European superiority over indigenous peoples are important parts of discovery. They believe that God has conferred them the rights to bring civilization, education, and religion to indigenous peoples and to exercise paternalistic and guardian powers over them. Europeans could acquire title to indigenous lands by military victories. Third, conquest. Conquest is also used as a term of art to describe the property and

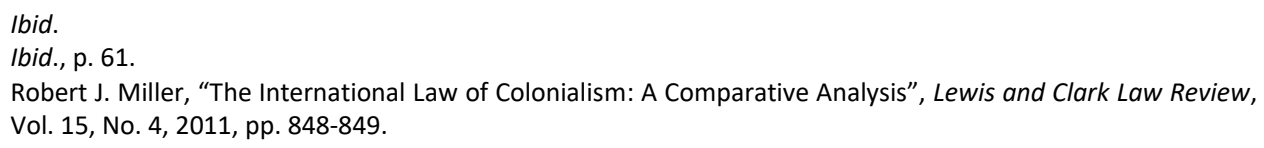


sovereign rights Europeans claimed automatically just by making a first discovery. Fourth, Christianity. Non-Christians are not deemed to have the same rights to land, sovereignty, and self-determination as Christians. ${ }^{25}$ The power and influence of the doctrine of Discovery in the formation of international law has clearly been stated by Miller as follows:

"The Doctrine of Discovery is one of the earliest examples of international law, that is, the accepted legal norms and principles that control the conduct of states versus other states. Discovery was specifically developed to control European actions and conflicts regarding exploration, trade, and colonization of non-European countries, and it was used to justify the domination of non-Christian, non-European peoples. The Church, England, Spain, Portugal, and France developed it in Europe over many centuries. Europeans rationalized that the Discovery Doctrine was permitted under the authority of the Christian God, and the ethnocentric idea that Europeans had the right to claim the lands-as well as the sovereign and commercial rights-of Indigenous peoples around the world."26

\section{De-colonization of International Law}

The foregoing discussion reveals that the European colonialism and their hegemony of values have put down international law as merely their legal and political instrument to divide the World into civilized West and uncivilized nonEuropean nations, and that is justifying the universalization of European values and traditions. Jean d'Aspremont neatly stated, it is also uncontested that, following its systematization by European scholars, international law was incrementally extended to non-European nations, sometimes with imperialistic aspirations. It is not only international law that was disseminated around the world on this occasion but also the European legal thought. ${ }^{27}$ Onuma observed that it was a society where the overwhelming majority of human beings were under the system of colonies, protectorates, protected nations, or were formally independent nations but substantially suffering from the consequences of unequal treaties with the imperial powers. European international law played a critical role in creating this unequal international society. ${ }^{28}$ Bedjaoui insisted that the European colonialism over international law was more robust and legitimate as it gained religious, political,

lbid., pp. 853-854.

lbid., p. 854.

Jean d'Aspremont, "International Law in Asia: The Limits to the Western Constitutionalist and Liberal Doctrines", Asian Yearbook of International Law, Vol. 13, 2008, p. 89.

28 Yasuaki Onuma, "When was the Law of International Society Born?", Journal of the History of International Law, Vol. 2, No. 1, 2000, p. 64. 
and economic justification, that is, Christian as its religious basis, imperial as its political objectives, and mercantilist as its material underpinnings. ${ }^{29}$

De-colonization of international law does not necessarily mean that it is removing all European legacies in the formation of international law. Some have argued that, notwithstanding its parochial origins and growth in Europe, the genius of international law is that, it has become universal and it governs states of all civilization, European and non-European. The Euro centricity notwithstanding, international law has become universal. ${ }^{30}$ Hence, de-colonization aimed at eliminating the substances and colonial practices in international law, as colonialism is actually a free rider in the formation of international law. In this context, the decolonization of international law is not related to the procedures and mechanism in the formation of international law, as it is relatively democratic. It is a matter of the substance of international law. Nevertheless, some have observed that the making of international law is still undemocratic because much of international law is touted as consensual, in fact, propounded by judges, academics, NGOs, and powerful nations with little input from developing countries. Customary international law has taken a different path, as it is the law of scholars, NGOs, and at times international tribunals not of nations or people. ${ }^{31}$ However, this is a matter of the substance or material source of international law, not a procedural concern. Developing countries have observed that customary international laws are considered as undemocratic because the material elements are mostly representing the interests of Western countries. In addition, developing countries view that they are not part and involved in the formation of such practices.

The removal elements and practices of international law that are considered smack of colonialism should be put in the framework of interpreting the law in accordance with the essence and universality of international law, not with the interpretation that associated with the spirit of European colonialism. The foregoing discussion also reveals that several international legal terms that form modern international law such as sovereignty, civilized nations, territoriality, and discovery is the political instrument to justify the European colonial practices. By using a unilateral and colonialistic approach, these terms have been legal and political devices to put non-European countries as merely the object and periphery element in the formation and application of international law. How do permanent members of the Security Council read and apply the veto right is the best example

29 M. Bedjaoui, "General Introduction" in M. Bedjaoui (ed.), International Law: Achievements and Prospects, Netherlands: Martinus Nijhoff, 1991, p. 6.

30 Surya Prakash Sinha, Legal Polycentricity and International Law, North California: Carolina Academic Press, 1996, p. 15.

31 J.Patrick Kelly, "International Law and the Shrinking Space for Politics in Developing Countries", Research Paper Series No. 08-31, Widener University School of Law, 2012, pp. 590-591. 
of how colonial interpretation is adopted in modern international law. Borrowing Jessup's words, the justification for granting this exceptional status to five members was due to the fact that they were 'inescapable fact of power differentials". The basic premise was that upon these members would fall the brunt of the responsibility for maintaining international peace and security, and therefore they must have the final or decisive vote in determining how that responsibility should be exercised..$^{32}$ In other words, the five permanent member states of the Security Council should use the right based on objective considerations, not of their subjective judgment. In fact, during the Cold War the veto right has mostly been used for protecting the interests of superpowers (the US and the Soviet Union) and it had nothing to do with the purpose of maintaining international peace and security. In the end, the destiny of veto right is still as it was, to perpetuate the domination and control of the five permanent member states in international politics for the sake of their national interests.

\section{E. Harmony of Norms: Moving from Otherness to Togetherness}

The evolution and development of international law implicate an extensive and complicated process. Weeramantry has identified five important phases in this development. The first phase was mainly philosophical in which the natural law philosophy played an important role and triggered off the emergence of international law. It provided the general outline of international law and the framework for its emergence as a new discipline. The second phase was that international law had been designed as a framework for the enterprise of territorial expansion and colonialism through the penetration of the European value system and the political support from European colonialism. In this period, international law provided a very exclusive and full privilege of norms to European countries, which eventually formed a sort of international club and the imperial system. International law in this phase continued for some countries till the age of traditional empires came to an end. ${ }^{33}$

The third phase begins when a number of new countries had been part of the international club and adhered to the international legal system, which in fact it was a product of colonialism and imperialism and they demanded equality of rights. However, their aspirations for obtaining full equality of the new members of the world community were hampered by the escalation of ideological confrontation between capitalism and communism. International law was very vulnerable to parochial interests resulted from this ideological confrontation. As a result, the new countries did not have a chance to contribute their culture and value in the development of international law. The fourth phase began after the

D.W. Bowett, The Law of International Institutions, London: Stevens, 1982, p. 28.

C. Weeramantry, Universalising International Law, Leiden: Martinus Nijhoff Publishers, 2004, p. 4. 
end of the Cold War, which was followed by the domination of Western capitalism. The characteristic and orientation of international law were not much different from before; the difference lies only in the form of political domination - from bipolar to unipolar. The cultural diversity and values of the world were still stored as ideal expectations and had not yet optimally enriching international legal norms that capable of making it a universal law. In the fifth phase, international law entered into the globalization era. International law obtained new hope as it potentially received input from a cross-cultural and inter-disciplinary scholarship, which in turn will make it as the global international community law. It is interesting to note that these changes are not carried out by military or economic force, as it happened in the colonial era, but from the world of scholarship. In other words, international law in this era is a product of consciousness and the work of the world of scholarship, because it is regarded as a neutral and effective force to admit the diversity of cultures and values of the world.

The second phase had been an important and decisive period in the formation of international law due to the fact that the substance and its influence are factual in today's practice. It can be seen for instance from the words of Henry Wheaton as follows:

"Is there a uniform law of nations? There certainty is not the same one for all the nations and states of the world. The public law, with slight exceptions, has always been, and still is, limited to the civilized and Christian people of Europe or to choose of European origin." ${ }^{34}$

Bluntschli insisted that international law lay on a foundation of natural law, which carried universal extension and did not depend on the specificity of different cultural forms. This view showed how the universality of (Western) universal law held up compatibly with the relativism of cultures and religions. ${ }^{35}$ The European nations had a view that from the $16^{\text {th }}$ to the $18^{\text {th }}$ century was that their jus gentium (the law of peoples) carried universal meaning and applications. This represents the popular belief of international lawyers in the late $18^{\text {th }}$ century and interestingly this still exists in certain practices of modern international law today. Weeramantry has observed that the international law developed in this era contained the following drawbacks as follows: ${ }^{36}$

a. Excessive reliance on a positivistic as opposed to a natural law approach.

b. Unawareness of other cultures.

c. The sacrosanct status accorded to state sovereignty.

34 Henry Wheaton, Elements of International Law, Washington D. C.: Carnegie Institute of Washington, 1964, p. 15.

35 J.C. Bluntschli , Das Moderne Volkerrecht, $2^{\text {nd }}$ edition, Nördlingen: Beck'sche Buchhandlung, 1968, p. 55.

36 Weeramantry, op.cit., p. 9. 
d. Failure to appreciate the large number of basic international law principles on which there would be common agreement across the cultures.

e. Insensitivity to the rights of non-Western peoples.

f. Imposition upon other cultures of concepts and procedures of western law.

More importantly, the second period created norms of international law with a palpable objective are to divide the world into "selves" (European nations) and "others" (non-European nations). Pahuja added that in the post coloniality of international law, from the very beginning international law had to posit, contain and differentiate between selves and others. ${ }^{37}$ European colonialism and imperialism had allowed their values and traditions to become hegemonic norms that ultimately produced the paradigm of "otherness" in international law. NonEuropean nations are "others", which are considered merely as users of the European values. For all the positivistic constructions of international law, the Asian and African remained 'others'. Pahuja states further:

"We must decide between the myth of universality and nihilism of cultural relativism; the oscillation should be understood and embraced as symptomatic of the post-colonial quality of law and the radical impossibility of closure it generates." 38

In its development, the "otherness" paradigm produces a variety of discriminatory terminologies such as superpower and non-superpower nations, developed and developing countries. Gustavo Gozzi, for instance, observed that the mandate system was an advance on the earlier system of protectorates. These last were based on international treaties between an administrating power and a protected nation. The mandate, in contrast, would establish a mission carried out on behalf and under the control of the community of nations. The basis for it was the colonized nation's assumed inability to sustain itself, coupled with a need for support and protection, which the mandatory power would provide until the condition obtained for the colonized nation's self-sustainment. ${ }^{39}$

The "otherness" paradigm in international law is resulted from the universal claim of the European values and that international law is nothing but the universalization of European values and traditions. Koskenniemi has observed that ".... for the universal has no voice, no authentic representative of its own. It can only appear through something particular: only a particular can make the universal known. A danger and a hope are involved. The danger is that of mistaking one's preferences and interests for one tradition - and then thinking of these as

\footnotetext{
S. Pahuja, "The Postcoloniality of International Law", Harvard Journal of International Law, Vol. 46, No. 2, 2005, p. 462.

Ibid., p. 468.

39 Gustavo Gozzi, "History of International Law and Western Civilization", International Community Law Review, Vol. 9, Issue 4, 2007, p. 18.
} 
universal, a mistake we Europeans have often made". ${ }^{40}$ It was a hegemonic technique. ${ }^{41}$

Moving from "otherness" to "togetherness" requires a paradigm shift in the making of international norms, from claim to consent approach. After the Second World War, there was a strong indication to abandon the "otherness" paradigm in international law due to the fact that the law has reached to and is applied by nonEuropean nations. It was the consent of these nations (international community) that formed the existence of the modern international law, and at the same time recognizing the diversity of values and cultures that shaped the international legal systems. State consent in terms of participating in non-European nations in the formation of modern international law is an important element because it had enriched and strengthened the substance of international law. Gustavo Gozzi insisted that this contribution was two-fold, for, on the one hand, these nations played a part in developing international law and making it a universal institution proper, while at the same time they helped to differentiate it. ${ }^{42}$ After the Second World War developing countries began to take a significant role in the formation of international law. For example, the Bandung Message, which was a product of the Asian-African Conference in 1955, produced some universal issues such as human rights, equality, anti-discrimination, self-determination, etc. This can certainly be considered a way in which the countries of Asia and Africa have contributed to the development of international law with a view to its universalization. ${ }^{43}$

The consent approach needs international law bound to reflect the new social composition of different nations. International law should move from its Eurocentric character or replication of European national law to become a common law of mankind. ${ }^{44}$ It contains a set of principles in which different civilizations makes it as a basic framework on which positive international law build. ${ }^{45}$ Some have proposed the difference between the making and the application of international law. International law must be built from a blended of different values and cultures that ultimately formed the substance of international law. In contrast, when international law is transformed into national law, the effort is rather to adapt the single standard to the different cultures meant to receive it, with an appropriate selection of means and procedures by which to make that standard effective in context. ${ }^{46}$

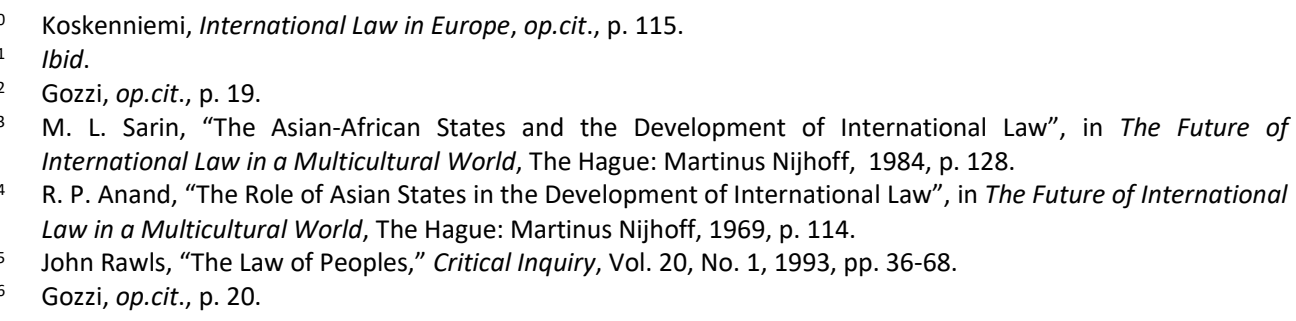


The togetherness paradigm, borrowing the words of Onuma, requires an intercivilizational approach. ${ }^{47}$ This approach will change the formation of international law, from top-down into a bottom-up approach that emphasizes equality among nations and away from discrimination. This will eventually capable of establishing a common ground or a common platform that will be the main element of the universality of international law. Onuma suggests that it is necessary to establish a theory, which takes into consideration various human aspects - from logical reasoning to historical legacies and emotional responses. ${ }^{48}$

\section{F. Making International Law is Really International in Nature}

Universality is a keyword of international law. Some have observed that international law tends to focus on the universal, the supranational, while comparativists attend to the local, the particular. ${ }^{49}$ Universal norms should not be put on an abstract level; they need transformation into the particular idioms. ${ }^{50}$ Universality is not a matter of claim; it is a respect and acceptance of cultures and values of other nations. Weeramantry, former Vice President of the ICJ has specifically discussed the influence, which the new scholarship from the nonWestern world, of which he is a part off, had on the construction of modern international law. He perceived and developed international law as a 'Global Construct', not a 'Western construct'. He referred to the concept of international law developed by Muslim Jurist, Hassan Shaybani, who viewed international law as the law of mankind. ${ }^{51}$ Regarding the indifference of positive international law in terms of its respect and acceptance of the culture and values of non-European nations, Weeramantry has observed that the unilateral development of international law suffered from:

"...neglect of other cultures...(international law was) largely a monocultural construct...there was also neglect of...the natural law background from which international law had its beginning...scientific progress had attracted great admiration.... and the law, in imitation of science, wished to vein itself as a scientific and objective discipline." 52

Since the Second World War international institutions have been more exposed to the cultural and social pluralism of the world, the sources upon which they draw

47 Onuma, op.cit., p. 66.

48 Yasuaki Onuma, "In Quest of Intercivilizational Human Rights: Universal vs. Relative Human Rights Viewed from an Asian Perspective", in D. Warner (ed.), Human Rights and Humanitarian Law: The Quest for Universality, The Hague: Martinus Nijhoff, 1997, p. 61.

49 David Kennedy, "The Disciplines of International Law and Policy", Leiden Journal of International Law, Vol. 12, No. 9, 1999, p. 82.

50 Teemu Ruskola, "Where is Asia? When is Asia? Theorizing Comparative Law and International Law", UC Davis Law Review, Vol. 44, Issue 3, 2011, p. 112.

51 Singh, op.cit., p. 79.

52 C. Weeramantry, "International Law and the Developing World: A Millenial Analysis", Harvard Journal of International Law, Vol. 41, No. 2, 2000, p. 278. 
have changed. ${ }^{53}$ The decisions of the ICJ have shown a marked reference to the ancient laws of Hinduism, Islam, and Buddhism as discussed above. It is no more simply a 'Western' construct. ${ }^{54}$ The establishment of variety world courts, however, has brought with them the problem of the indetermination of international law. This is the fragmentation of international law, which is a step towards the construction of true international law. It is simply a crisis of a nascent and newly de-colonized international law. ${ }^{55}$ Fragmentation and unity are matters of narratives. ${ }^{56}$ But given the fact that these international courts and tribunals now have greater representation from third world countries, more than ever, the decisions by them will help to dilute positive international law and make international law truly natural law. ${ }^{57}$ In other words, it makes international law truly international in nature.

\section{G. Global Constitutionalism}

Global constitutionalism is an agenda of international law reform by applying the ideas of constitutional law. The core idea of constitutionalism is the organization and institutionalization of power. This is a response to global problems due to the absence of effective organization and institutionalization of power in international law. In the context of global society, the transformation of the concept of constitutionalism to international law will involve complicated areas and processes. There are at least four main dimensions of constitutionalism as the foundation for the formation of global constitutionalism: social constitutionalism; institutional constitutionalism; normative constitutionalism; and analogical constitutionalism.

\section{Social Constitutionalism}

Social constitutionalism emphasizes the need for participation of the international community in international lawmaking. International law should provide a forum for such participation as a check and balances mechanism to confine an absolute power of states and at the same time justifies for rule based-power. Global constitutionalism requires the international community as an order of co-existence. The participation and accountability of the international community is the core vision of global constitutionalism. There are two approaches to explain the social dimension of global constitutionalism; the international community school, and the idea of a global civil society.

\footnotetext{
53 Y. Atal, "Outsiders as Insiders: The Phenomenon of Sandwich Culture", Sociological Bulletin, Vol. 38, 1989, p. 23.

54 Singh, op.cit., p. 80

55 M. Koskenniemi, "Constitutionalism as Mindset: Reflections on Kantian Themes about International law and Globalisation", Theoretical Inquiries in Law, Vol. 8, 2007, p. 9.

56 M. Koskenniemi, From Apology to Utopia: The Structure of International Legal Argument, Cambridge: Cambridge University Press, 2005, pp. 474-512.

57 Singh, op.cit., p. 81.
} 
The international community school puts the international community as a social basis for the existence of global constitutionalism because the international community needs norms for governing their social relations and interactions. Fassbender argues that there has been a paradigm shift in international law, from the 'sovereignty-centered system' to the 'value-oriented or individual-oriented system'. ${ }^{58}$ In this context, the international community is no longer identical with States as its membership, but also other subjects of international law such as international organizations, or even global citizens. Herman Mosler argues that the international community is a legal community because it consists of states and nonstate actors that should be governed by a special legal regime (distinct law). ${ }^{59}$ Christian Tomuschat, one of the proponents of the international community integration approach insists that one of the functions of global constitutionalism is to confine political power both at national and international levels in the interests of world peace, individual rights, and respect for the law (rule of law). Tomuschat emphasizes two main themes in global constitutionalism namely, limitation of power, and institutionalization of power. ${ }^{60}$ The global civil society approach suggests that individuals can and must take part in international forums, which is called 'civil society' or 'international society'. In the context of national law is referred to as 'constitutional democracy'. The two approaches require the four main themes of constitutionalism namely; restrictions on power, governance, protection of individual rights, and social idealism. These are the main premise of all visions of global constitutionalism. ${ }^{61}$

\section{Institutional Constitutionalism}

Institutional constitutionalism pertains to the idea of limitation and accountability of power through participation and representation. Participation and accountability (allocation of power) is the main idea for the institutionalization of power. Schwobel states: "... it is often believed that participation and accountability can be best achieved through the establishment of institutions". If it is associated with the main theme of global constitutionalism, then the two main themes would be the

58 Bardo Fassbender, "The meaning of international constitutional law", in Nicholas Tsagourias (ed.), Transnational Constitutionalism: International and European Perspectives, Cambridge: Cambridge University Press, 2007, p. 546; See also Christian Tomuschat, "International Law: Ensuring the Survival of Mankind on the Eve of a New Century", General Course on Public International Law, Requil des Cours de l'Academie de Droit International, Vol. 281, 1999, p. 287.

59 Herman Mosler, The International Society as Legal Community, Alphen aan den Rijn: Stijhoff \& Noordhoff, 1980, p. 50.

60 Tomuschat, op.cit., p. 23.

61 Philip Allot, "The Emerging International Aristocracy", New York University Journal of International Law and Politics, Vol. 35, 2003, p. 336; Philip Allot, Eunomia: New Order for a New World, Oxford: Oxford University Press, 1990, p. XIX; Philip Allot, The Health of Nations, Cambridge: Cambridge University Press, 2002, p. XI; Philip Allot, "Reconstituting Humanity - New International Law", European Journal of International Law, Vol. 11, No. 3, 1992, p. 225. 
main issues of institutional constitutionalism; the limitation of power, and the institutionalization of power.

Global governance, United Nations, and macro constitutionalism are the three main elements to strengthen institutional constitutionalism in international law. The increasing international cooperation in various aspects of human life cannot be fully managed by a domestic legal approach. There is a need for global governance to make cooperations are fair, just, and proportional. However, it does not necessarily mean that it leads to the establishment of the world law regime, it is a network of cooperation. Anne Peters states, "... a network of constitutions that traverse both the national and the international legal orders". ${ }^{62}$ In the context of the relations between domestic and international law, then the relations between the two legal systems are no longer hierarchical, but a network. Anne Peters further explains: "... this relationship between international and national law is thus" a network "rather than" a hierarchy of rules. "63

The United Nations is the palpable and authoritative form of institutionalization of power in international law. The UN Charter with its various innate weaknesses has widely been accepted as the constitution of the international community. Schwobel states:"... since the United Nations is the only organization that boasts near universal membership and is thus considered as the primary institutional representative of the international community, it is explained as fulfilling the requirements of universality that a global constitution demands ". ${ }^{64}$

Macro constitutionalism pertains to practices in international law, where the constitution of an international organization, which because of the scope of its activities and jurisdiction covers almost all countries and they cannot avoid it unless they become part of the constitution of that organization. ${ }^{65}$ Therefore, there is a transformation process from micro to macro-constitutionalism. For example, States are members of the World Trade Organization (WTO) or the International Labor Organization (ILO), because the organizations work on the field or area that constitute the needs of all people in the World.

\section{Normative Constitutionalism}

Normative constitutionalism is based on the idea that an international order must be supported by the operation of superior constitutional norms. This represents the paradigm shift in international law from state interests towards state rights and obligations. The paradigm of international law has shifted from state consent to

\footnotetext{
62 Anne Peters, "Compensatory Constitutionalism: The Function and Potential of Fundamental International Norms and Structures", Leiden Journal of International Law, Vol. 19, 2006, p. 580.

63 Anne Peters, "Global Constitutionalism in a Nutshell" in Liber amicorum Jost Delbruck, Berlin: Duncker \& Humblot $\mathrm{GmbH}, 2005$, p. 580.

64 Schwobel, op.cit., p. 31.

65 See Anne Peters, "The Merits of Global Constitutionalism", Indiana Journal of Global Legal Studies, Vol. 16, 2009 , p. 408.
} 
global values such as: 'public interest norms, fundamental norms, and international community norms'. The best example of normative constitutionalism is jus cogens norm. Normative constitutionalism covers all the main themes of global constitutionalism as stated above namely, limitation of power, the institutionalization of power, social idealism, standard-setting, and protection of individual rights. The normative constitutionalism focuses on the protection of rights, especially individual rights. Maduro states: "The fundamental fear is that of the many. The fundamental suspicion lies in the political process. Consequently, power is transferred to alternative institutions (courts, international organizations, the market), which are idealized, a notion which mirrors the idealism of the norms that are to be protected". 66

\section{Analogical Constitutionalism}

Analogical constitutionalism is an idea to justify the application of principles and the forms of constitutions at both the regional and national level in international law. Theoretically, analogical constitutionalism is based on the so-called 'meta-rules constitutionalism' which the idea, among others, is developed by Alfred Verdross. He states as follows: "those norms which deal with the structure and sub-divisions of, and the distribution of spheres of jurisdiction in a community ". ${ }^{67}$ In other words, constitutionalism meta-rules relates to the development of a society based on a planned or a definite system, which is standardized in procedural forms. Tomuschat adds, "... rules on how the bulk of the other rules are produced, how they enter into force, how they are implemented and who, in case of difference over their interpretation and application, are empowered to settle ensuing dispute". 68

There are several considerations that should take into account for the application of the principles of the domestic constitution at the international level. Robert Uerpmaan identified three main elements. First, the constitution must have the main institution which is the subject of the constitution, and the United Nations is eligible for this. Secondly, the constitution of international law must have a legislation system. With some of its shortcomings, international law has a doctrine regarding the source of law. Thirdly, international law has a branch of judicial power, the International Court of Justice. ${ }^{69}$ The absence of an executive branch is still one of the shortages of international law. Analogical constitutionalism emphasizes on the idea that law is a system. On that basis, the law as a system,

66 Miguel Poiares Maduro, "From Constitution to Constitutionalism: A Constitutional Approach for Global Governance " in Douglas Lewis (ed.), Global Governance and the Quest for Justice, Oxford: Hart Publishing, 2006, p. 242.

67 Schwobel, op.cit., pp. 43-44.

68 Christian Tomuschat, "Obligation Arising for States Without or Against Their Will" Requil des Cours de l'Academie de Droit International, Vol. 241, 1993, p. 216.

69 Schwobel, op.cit., p. 45. 
including constitutional law must be applied in various areas and jurisdictions, including international law.

\section{H. Concluding Remarks}

The modern international law, not only imitates, but the substance is truly the European values and traditions. The hegemony of European values and colonialism are the most crucial factors that made modern international law are associated with the values and traditions of the European nations. They enjoyed their superiority norms and practices that ultimately made the European were confident to declare and claim as a major or even the sole contributor to the establishment of the law of nature and law of nations (international law). Modern international law was formed in the era of colonialism that put Europe as the powerful nations and the powerless nation is non-European countries. Hence, colonialism and hegemony like the two sides of the one coin. The universalization of international law is principally the political by-product of European colonialism and imperialism.

De-colonization of international law does not necessarily mean that it is removing all the European legacies in the formation of international law. Decolonization aimed at eliminating the substances and colonial practices in international law, as colonialism is actually a free rider in the formation of international law. In this context, the decolonization of international law is not related to the procedure and mechanism in the formation of international law, as it is relatively democratic. It is a matter of the substance of international law. The removal elements and practices of international law that are considered smack of colonialism should be put in the framework of interpreting the law in accordance with the essence and universality of international law, not with the interpretation containing the spirit of European colonialism.

European colonialism and imperialism, which allow their values and traditions to become hegemonic norms that ultimately produce the paradigm of "otherness" in international law. Non-European nations are "others", which are considered only as users of the European values. For all the positivistic constructions of international law, the Asian and African remained 'others'. The "otherness" paradigm in international law is resulted from the universal claim of the European values. In other words, international law is the universalization of values or even universalization of European languages.

Global constitutionalism is an agenda of international law reform by applying the idea and concept of constitutional law. The core idea of constitutionalism is the organization and institutionalization of power. This is a response to global problems due to the absence of effective organization and institutionalization of power in international law. In the context of global society, the transformation of the concept of constitutionalism to international law will involve complicated areas and processes. There are at least four main dimensions of constitutionalism as the 
foundation for the formation of global constitutionalism: social constitutionalism; institutional constitutionalism; normative constitutionalism; and analogical constitutionalism. Social constitutionalism emphasizes the need for the participation of the international community in international lawmaking. International law should provide a forum for such participation as a check and balances mechanism to confine an absolute power of states and at the same time justifies for rule based-power. Global constitutionalism requires the international community as an order of co-existence. The participation and accountability of the international community is the core vision of global constitutionalism.

\section{References}

\section{Books}

Anand, R.P., "The Role of Asian States in the Development of International Law", in The Future of International Law in a Multicultural World, Martinus Nijhoff, The Hague, 1969.

Allot, Philip, Eunomia: New Order for a New World, Oxford University Press, Oxford, 1990.

, The Health of Nations, Cambridge University Press, Cambridge, 2002.

Bluntschli, J.C., Das Moderne Volkerrecht, $2^{\text {nd }}$ edition, Beck'sche Buchhandlung, Nördlingen, 1968.

Bowett, D.W., The Law of International Institutions, Stevens, London, 1982.

Henry Wheaton, Elements of International Law, Carnegie Institute of Washington, Washington D. C., 1964.

Herman Mosler, The International Society as Legal Community, Stijhoff \& Noordhoff, Alphen aan den Rijn, 1980.

Martti Koskenniemi, From Apology to Utopia: The Structure of International Legal Argument, Cambridge University Press, Cambridge, 2005.

, The Gentle Civilizer of Nations: The Rise and Fall of International Law 1870-1960, Cambridge University Press, Cambridge, 2011.

Norman Etherington, Theories of Imperialism: War, Conquest and Capital, Rutledge Revivals, New York, 1984.

Sinha, Surya Prakash, Legal Polycentricity and International Law, Carolina Academic Press, North California, 1996.

Weeramantry, Christopher, Universalising International Law, Martinus Nijhoff Publishers, Leiden, 2004.

\section{Other Documents}

Allot, Philip, "Reconstituting Humanity - New International Law", European Journal of International Law, Vol. 11, No. 3, 1992.

, "The Emerging International Aristocracy", New York University Journal of International Law and Politics, Vol. 35, 2003. 
Anghie, Antony, "The Evolution of International Law: Colonial and Postcolonial Realities", Third World Quarterly, Vol. 27, No. 5, 2006.

Atal, Y., "Outsiders as Insiders: The Phenomenon of Sandwich Culture", Sociological Bulletin, Vol. 38, 1989.

Bedjaoui, M., "General Introduction" in M. Bedjaoui (ed.), International Law: Achievements and Prospects, Martinus Nijhoff, Netherlands, 1991.

d'Aspremont, Jean, "International Law in Asia: The Limits to the Western Constitutionalist and Liberal Doctrines", Asian Yearbook of International Law, Vol. 13, 2008.

Fassbender, Bardo, "The meaning of international constitutional law", in Nicholas Tsagourias (ed.), Transnational Constitutionalism: International and European Perspectives, Cambridge: Cambridge University Press, 2007,

Gozzi, Gustavo, "History of International Law and Western Civilization", International Community Law Review, Vol. 9, Issue 4, 2007.

Gathii, James Thuo, "Imperialism, Colonialism, and International Law", Buffalo Law Review, Vol. 54, No. 4, 2007.

Kennedy, David, "The Disciplines of International Law and Policy", Leiden Journal of International Law, Vol. 12, No.9, 1999.

Kelly, J. Patrick, "International Law and the Shrinking Space for Politics in Developing Countries", Research Paper Series No. 08-31, Widener University School of Law, 2012.

Koskenniemi, M., "Constitutionalism as Mindset: Reflections on Kantian Themes about International law and Globalisation", Theoretical Inquiries in Law, Vol. 8, Issue 1, 2007.

, "International Law in Europe", European Journal of International Law, Vol. 16, No.1, 2005.

, "Histories of International Law", Rechtsgeschichte, Vol. 19, 2011.

L. Sarin, M., "The Asian-African States and the Development of International Law", in The Future of International Law in a Multicultural World, Martinus Nijhoff, The Hague, 1984.

Maduro, Miguel Poiares, "From Constitution to Constitutionalism: A Constitutional Approach for Global Governance " in Douglas Lewis (ed.), Global Governance and the Quest for Justice, Hart Publishing, Oxford, 2006.

Miller, Robert J., "The International Law of Colonialism: A Comparative Analysis", Lewis and Clark Law Review, Vol. 15, No. 4, 2011.

Minoglo, Walter D., "The Making and Closing of Eurocentric International Law: The Opening of a Multipolar World Order", Comparative Studies of South Asia, Africa and the Middle East, Vol. 36, Issue 1, 2016.

Onuma, Yasuaki, "In Quest of Intercivilizational Human Rights: Universal vs. Relative Human Rights Viewed from an Asian Perspective", in D. Warner (ed.), 
Human Rights and Humanitarian Law: The Quest for Universality, Martinus Nijhoff, The Hague, 1997.

, "When was the Law of International Society Born?", Journal of the History of International Law, Vol. 2, No. 1, 2000.

Pahuja, S., "The Postcoloniality of International Law", Harvard Journal of International Law, Vol. 46, No. 2, 2005.

Peters, Anne, "Compensatory Constitutionalism: The Function and Potential of Fundamental International Norms and Structures", Leiden Journal of International Law, Vol. 19, 2006.

, "Global Constitutionalism in a Nutshell" in Liber amicorum Jost Delbruck, Berlin: Duncker \& Humblot $\mathrm{GmbH}, 2005$.

, "The Merits of Global Constitutionalism", Indiana Journal of Global Legal Studies, Vol. 16, 2009.

Quijano, Aníbal, "Coloniality and Modernity/Rationality", Cultural Studies, Vol. 21, No. 2-3, 2007.

Rawls, John, "The Law of Peoples," Critical Inquiry, Vol. 20, No. 1, 1993.

Ruskola, Teemu, "Where is Asia? When is Asia? Theorizing Comparative Law and International Law", UC Davis Law Review, Vol. 44, Issue 3, 2011.

Singh, Prabhakar, "From 'Narcissistic' Positive International Law to 'Universal' Natural International Law: The Dialectics of 'Absentee Colonialism", African Journal of International and Comparative Law, Vol. 16, No.1, 2008.

Steiger, H., "From the International Law of Christianity to the International Law of the World Citizen: Reflections on the Formation of the Epochs of the History of International Law", Journal of the History of International Law, Vol.2, Issue 3, 2001.

Tomuschat, Christian, "International Law: Ensuring the Survival of Mankind on the Eve of a New Century', General Course on Public International Law, Requil des Cours de l'Academie de Droit International, Vol. 281, 1999, p. 287.

, "Obligation Arising for States Without or Against Their Will", Requil des Cours de l'Academie de Droit International, Vol. 241, 1993.

Weeramantry, Christopher, "International Law and the Developing World: A Millenial Analysis", Harvard Journal of International Law, Vol. 41, No.2, 2000. 